\title{
Arc parallel extension in Higher and Lesser Himalayas, evidence from western Arunachal Himalaya, India
}

\author{
Sharmistha De Sarkar, George Mathew* and Kanchan Pande \\ Department of Earth Sciences, Indian Institute of Technology, Bombay, Powai, Mumbai 400 076, India. \\ *Corresponding author.e-mail: gmathew@iitb.ac.in
}

The existence of E-W extensional features from northeast (NE) Himalaya is poorly documented. Our investigation in the western part of Arunachal Himalaya provides evidences of active Quaternary E-W arc-parallel extensional features in the Higher and Lesser Himalayas. They are represented by arcperpendicular normal faults and arc-parallel sinistral strike-slip faults. We discuss the occurrences of these arc-parallel extensional features in terms of oblique convergence and radial expansion models. The partitioning of stress due to oblique convergence is argued based on evidences of left-lateral slip in NEHimalaya, right-lateral slip in NW-Himalaya and absence of translation in the central part. The amount of arc-parallel extension in the hinterland regions is correlated to the amount of radial shortening in the foreland. The computation of arc-parallel extension in the NE Himalayan arc is carried out by defining a small-circle centered at $88^{\circ} 39^{\prime} \pm 0.7^{\prime} \mathrm{E}$ longitude and $33^{\circ} 40^{\prime} \pm 0.6^{\prime} \mathrm{N}$ latitude having a radius of $770.7 \pm 15.1 \mathrm{~km}$, for the segment between $92^{\circ} 01^{\prime}$ and $95^{\circ} 16^{\prime} \mathrm{E}$ longitudes. The amount of arc-parallel extension estimated is $\sim 110 \mathrm{~km}$ for the NE Himalayan segment. Our result agrees closely with the $104 \mathrm{~km}$ extension determined based on geodetically computed extension rate and age of initiation of rifting in southern Tibet.

\section{Introduction}

Intercontinental collision zones worldwide show common characteristics of horizontal shortening such as thickening of the crust and surface uplift. Crustal thickening often results in extension in the high elevated regions, while crustal shortening proceeds along the outer flanks of the uplifted ranges. Syntectonic extension in the high elevated Tibetan plateau and in the Himalayas is contemporaneous with crustal shortening in the foreland part, and constitutes an integral element of the mountain building phenomena (Burchfiel and Royden 1985; England and Houseman 1989; Murphy and Copeland 2005; Thiede et al. 2006). Various mechanisms and theories have been put forth to explain arc-parallel extension, however, the evolution of both normal and translational fault systems still remains a matter of debate (e.g., Murphy et al. 2002; Selverstone 2005; Hintersberger et al. 2010). Extension related normal fault features have been documented extensively in the Tibetan Plateau, Higher Himalaya and from parts of Lesser Himalaya (Hintersberger et al. 2010 and references there in). Murphy and Copeland (2005), Jessup et al. (2008), Leloup et al. (2010) and Hintersberger et al. (2010) documented active north-south striking younger brittle extensional structures overprinting the previously generated crustal scale faults in northwest (NW) Himalaya. In the northeast (NE) Himalaya with the exception of the Cona-Oiga rift, which is largely restricted to southern Tibet, no extension related normal faults/graben or strike-slip faults

Keywords. Arunachal Pradesh; Himalaya; normal fault; arc-parallel extension; oblique convergence; radial expansion. 


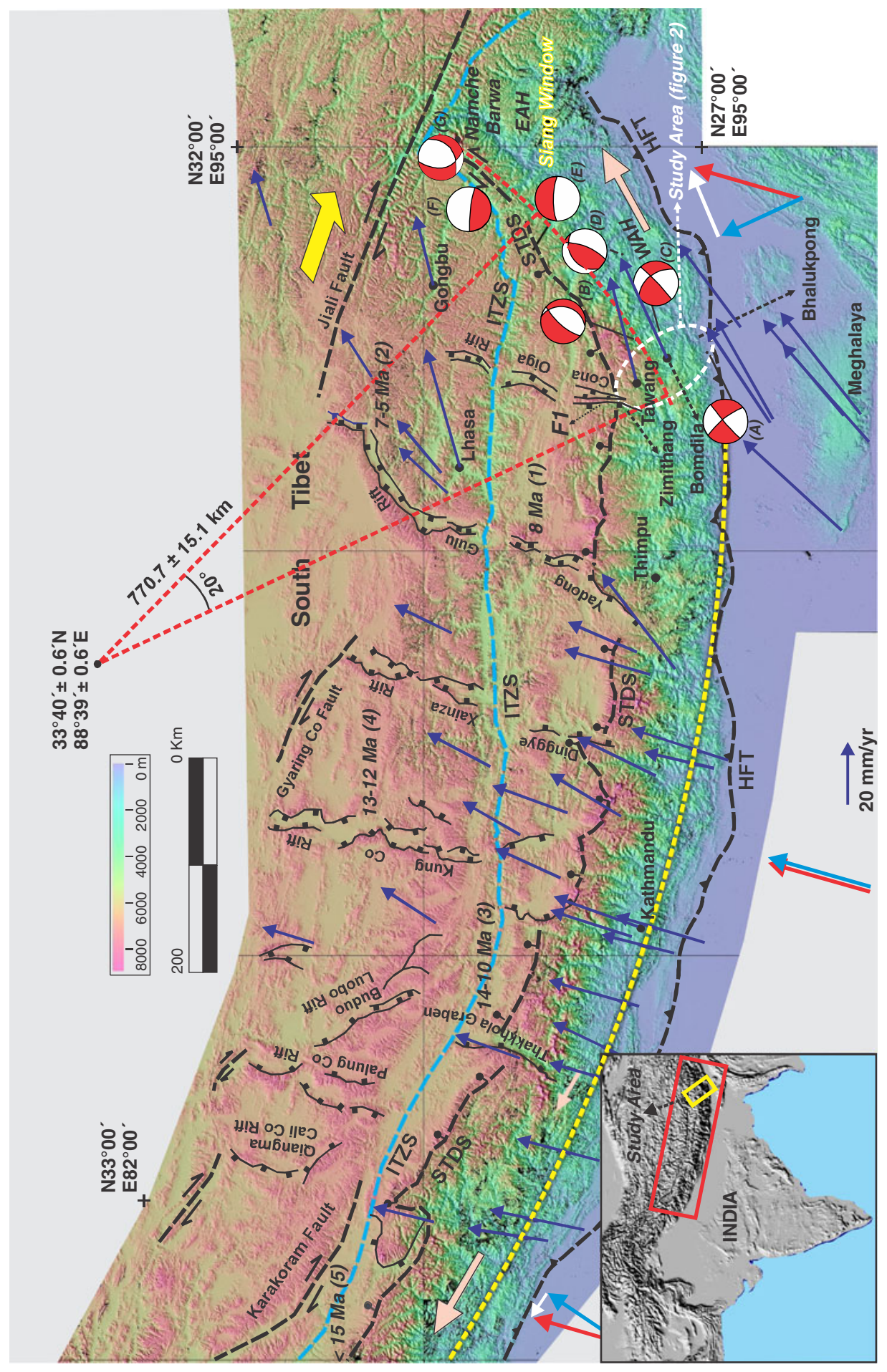

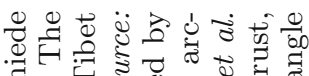

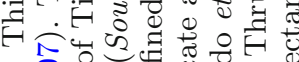

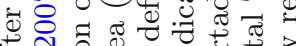

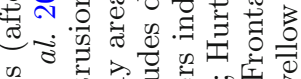

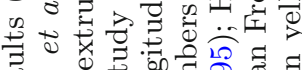

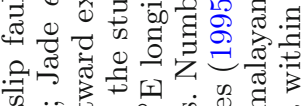

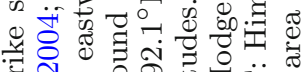

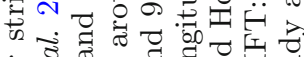
ธิ वृ

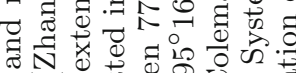

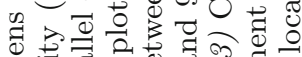
. 0.0 \%

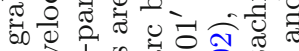
め0

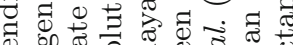

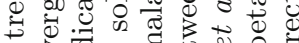
>

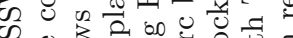
亿

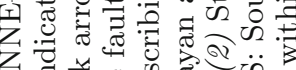
Z.

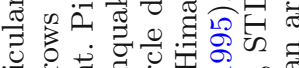
$\because \forall=.90$

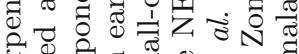
¿ै:

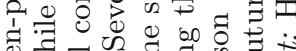

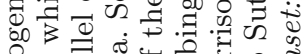

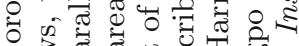

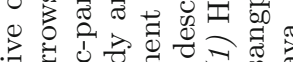

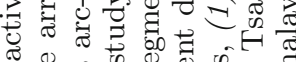

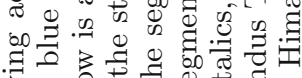
s.

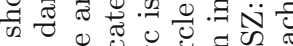

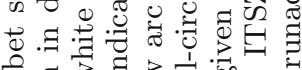

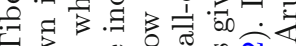
द्व

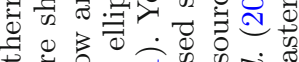

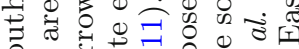

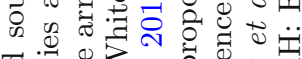
च :

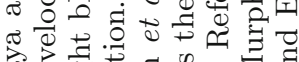

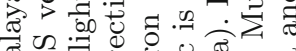

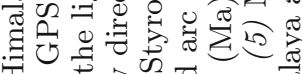
U. 유유

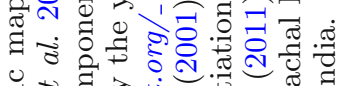
ษ \% ర人 ôn. -

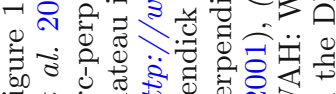

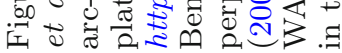


have been reported. The NE Himalayan regions still remain largely unexplored. Most earlier tectonic studies in the NE regions were focused on understanding the arc-parallel thrusts and extension to understand the geodynamic evolution of the eastern syntaxial zone. In the present paper, we document Quaternary features that record the transition from shortening to extension in the Higher and Lesser Himalayas of western Arunachal Pradesh (figure 1). In light of the field evidences and timing, we discuss the probable cause for extension related features in the NE Himalaya.

\section{Geological setting of the study area}

Arunachal Himalaya is the easternmost part of the Himalayan range trending ENE-WSW turning to NE-SW further east (figures 1 and 2). The Main Central Thrust or Se La thrust in Arunachal Pradesh has been correlated with Thimpu thrust in Bhutan and Darjeeling thrust in Darjeeling-Sikkim Himalaya (Valdiya 1980). The Arunachal Himalaya is divided into western and eastern domains by the Siang window (figure 1) (Singh and Chowdhary 1990; Acharyya 1998; Ding et al. 2001; Zeitler et al. 2001).

The study area in the western Arunachal Himalaya exposes three major sub-parallel northdipping regional thrusts; from south to north they are Himalayan Frontal Thrust (HFT), the Main Boundary Thrust (MBT) and the Main Central Thrust (MCT) (figure 2). The HFT places molasse deposits of the Siwalik Formation over the Brahmaputra plain. The foreland Siwalik Group in the Arunachal Himalaya consisting of the Dafla,

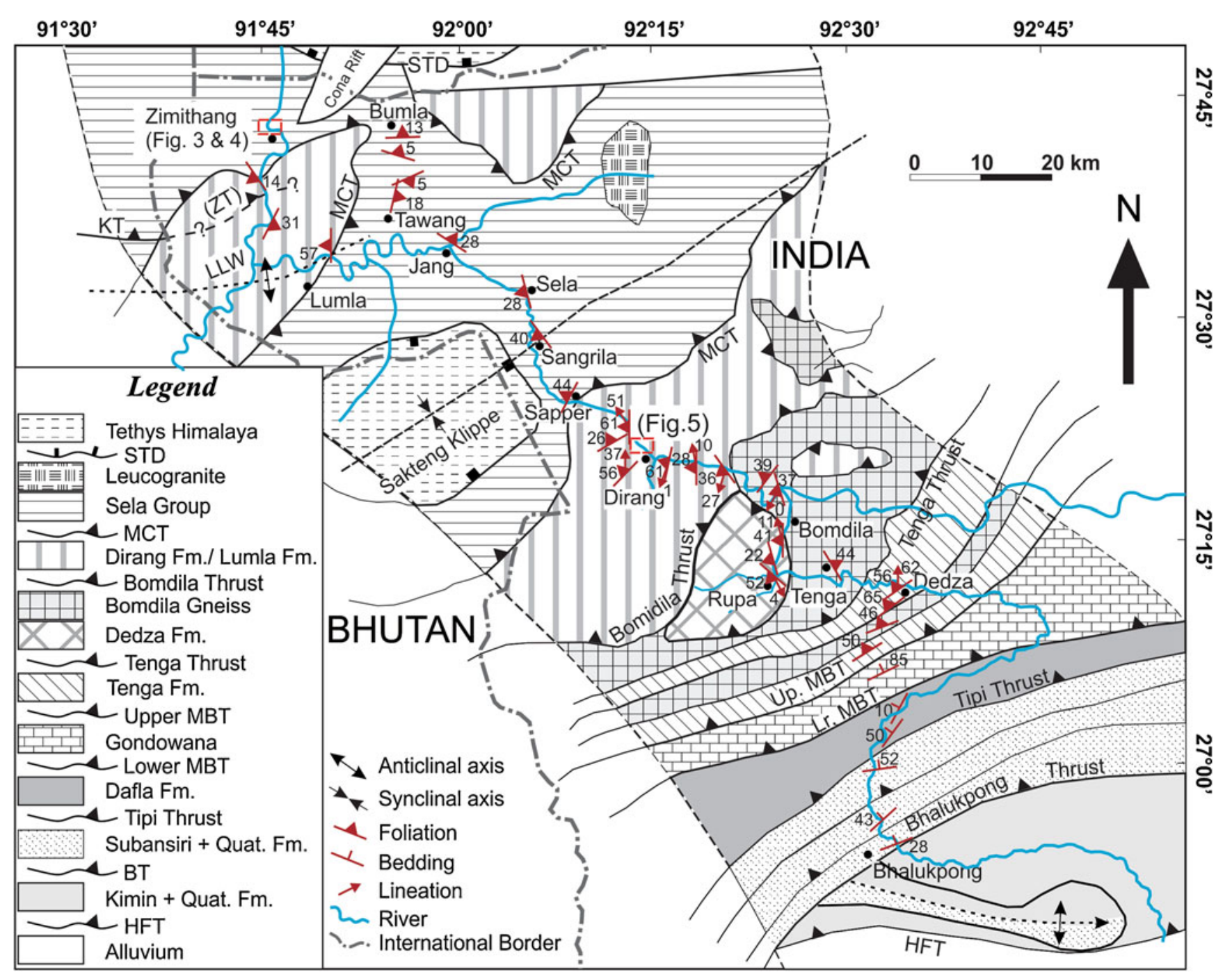

Figure 2. Geological map of western Arunachal Pradesh (modified after Kumar 1997; Bhattacharjee and Nandy 2007; Goswami et al. 2009; Yin et al. 2010) shows distribution of the different stratigraphic units in the area. Structural data based on traverses from Bhalukpong-Tawang and Tawang-Zimithang. STD: South Tibetan Detachment, KT: Kakthang Thrust, ZT: Zimithang Thrust, LLW: Lum-La Window, MCT: Main Central Thrust, MBT: Main Boundary Thrust, HFT: Himalayan Frontal Thrust, BT: Bhalukpong Thrust. 
Subansiri and Kimin Formation is bound between the MBT and HFT (figure 2) (Kumar 1997). The Lesser Himalayan sequence (LHS) lies in the hanging wall of the MBT and consists of varied rock types from south to north. In the south, marine and plant fossil bearing Permian Gondwana rocks are overlain by low-grade metamorphites of Tenga Formation and mylonitic gneiss. The garnet-kyanite-sillimanite schist of Dirang Formation lies thrusted along Bomidilla Thrust (BT). The LHS is overthrusted by the Greater Himalayan sequence (GHS) along the MCT. The Greater Himalayan Crystalline Complex is separated from Tethyan Himalaya by South Tibetan Detachment (STD) Fault which is a north dipping normal fault (figure 1). The Greater Himalayan Crystalline Complex in the Arunachal Himalaya consists of high grade migmatites, paragneiss, augen gneiss, amphibolites and Tertiary Leucogranites (Bhattacharjee and Nandy 2007; Kumar 1997; Goswami et al. 2009). The Tethyan sequence is not exposed in the study area. The GHS also host several MCT tectonic windows represented by lithologies equivalent of Dirang Formation. The present paper focuses on the western part of Arunachal Himalaya.

\section{Arc parallel extension}

\subsection{Higher Himalaya (Zimithang valley)}

The Himalayan-Tibetan orogen hosts numerous major active normal fault systems and grabens documenting general E-W extension that are distributed most extensively in the southern Tibetan plateau (figure 1). Most of them show strike at several places normal to the trend of the orogen (Molnar and Tapponnier 1978; Ni and York 1978; Armijo et al. 1986; Molnar and Lyon-Caen 1988; Ratschbacher et al. 1994). Fault plane solutions of earthquakes from Himalaya document thrustrelated radial shortening, while the Tibetan region shows extension-related pure normal faulting both in shallow and deeper crustal levels (Molnar and Chen 1983; Ni and Barazangi 1984; Seeber and Armbruster 1984). Geodetic results of Banerjee and Bürgmann (2002) reveal active E-W extension both in the internal parts of Himalaya and Tethyan region.

The N-S striking extensional faults and associated grabens are not only pervasive in the southern Tibet, but are also extensively developed in the Higher Himalayan zone along the entire orogen (figure 1). Most of the extensional features cut across earlier structures. These extensional structural features occur either as isolated normal faults or as linked graben systems (Armijo et al. 1986;
Molnar and Lyon-Caen 1988; Ratschbacher et al. 1994; Murphy et al. 2002; Thiede et al. 2006). A recent paper by Hintersberger et al. (2010) documented active $\mathrm{E}-\mathrm{W}$ extension throughout the NW Indian Himalaya. Their data indicate that the extension is not limited to the higher parts of the Himalaya, but is also found in the lower elevation regions as low as $1500 \mathrm{~m}$.

Although extensional structures in the NW Himalaya are well documented, the NE Himalaya still remains poorly documented. The major orogen perpendicular $\mathrm{N}-\mathrm{S}$ striking normal faults in the eastern part of southern Tibet and NE Himalaya are the Yadong-Gulu rift, which extends into the Higher Himalaya in Bhutan and the ConaOiga rift that extends into the Higher Himalayas of western Arunachal Pradesh (figure 1). The Cona-Oiga rift is about $120 \mathrm{~km}$ long and trends $\sim 12^{\circ} \mathrm{N}$. It lies between $89^{\circ}$ and $92^{\circ} \mathrm{E}$ longitudes and between $27^{\circ} 40^{\prime}$ and $31^{\circ} \mathrm{N}$ latitudes. It cuts the STD to the south and extends across the Yarlung Tsangpo Fault into the eastern Gangdese batholith zone to the north. The Cona-Oiga rift consists of three independent grabens. The southernmost Cona graben has a maximum width of $\sim 10 \mathrm{~km}$ and tapers at its southern end into the Arunachal Higher Himalaya (figure 1). The normal fault is located on the western margin of the basin and dips towards east. Two large earthquakes of M7.5 and M7.0 have occurred at the northern Cona in 1806 and southern Oiga in 1915, respectively (Zhong-hai et al. 2008).

In the present study, analysis of $30 \mathrm{~m}$ SRTM image first revealed an approximately north-south trending normal fault feature west of Cona rift. During our field investigation, this normal fault $\left(F_{1}\right)$ was observed close to Zimithang trending NNE-SSW and dipping west (figure 1). The $\mathrm{F}_{1}$ fault forms a half graben in the western side of the Cona rift close to its southern termination end in western Arunachal Pradesh (figures 1 and 3a, b). Similar to Cona rift, fault $F_{1}$ also cuts across the South Tibetan Detachment system (figure 1). The $\mathrm{F}_{1}$ half graben is about $60 \mathrm{~km}$ long and $7 \mathrm{~km}$ wide. This half graben seems to have collapsed within into another $\mathrm{N}-\mathrm{S}$ trending smaller graben of $\sim 2.5 \mathrm{~km}$ long and $2 \mathrm{~km}$ wide and is bound by faults $\mathrm{F}_{2}$ (figure $3 \mathrm{~b}$ ). Both the $\mathrm{F}_{1}$ half graben and $\mathrm{F}_{2}$ related graben have developed within the augen gneisses of Higher Himalaya. The $\mathrm{F}_{2}$ faults related graben at its southern end is bound by $\mathrm{E}-$ $\mathrm{W}$ trending vertical normal fault represented by the $\mathrm{F}_{3}$ fault scarp close to Zimithang. The scarp is $\sim 100 \mathrm{~m}$ high and extends for about $\sim 1 \mathrm{~km}$ along $\mathrm{E}-\mathrm{W}$ (figure $3 \mathrm{~b}$ and $\mathrm{c}$ ). The northern end of the graben is also bound by a similar fault $\left(\mathrm{F}_{4}\right)$ trending ENE-WSW, however is accompanied by sinistral slip (figure $3 \mathrm{~b}$ ). None of the north and south 

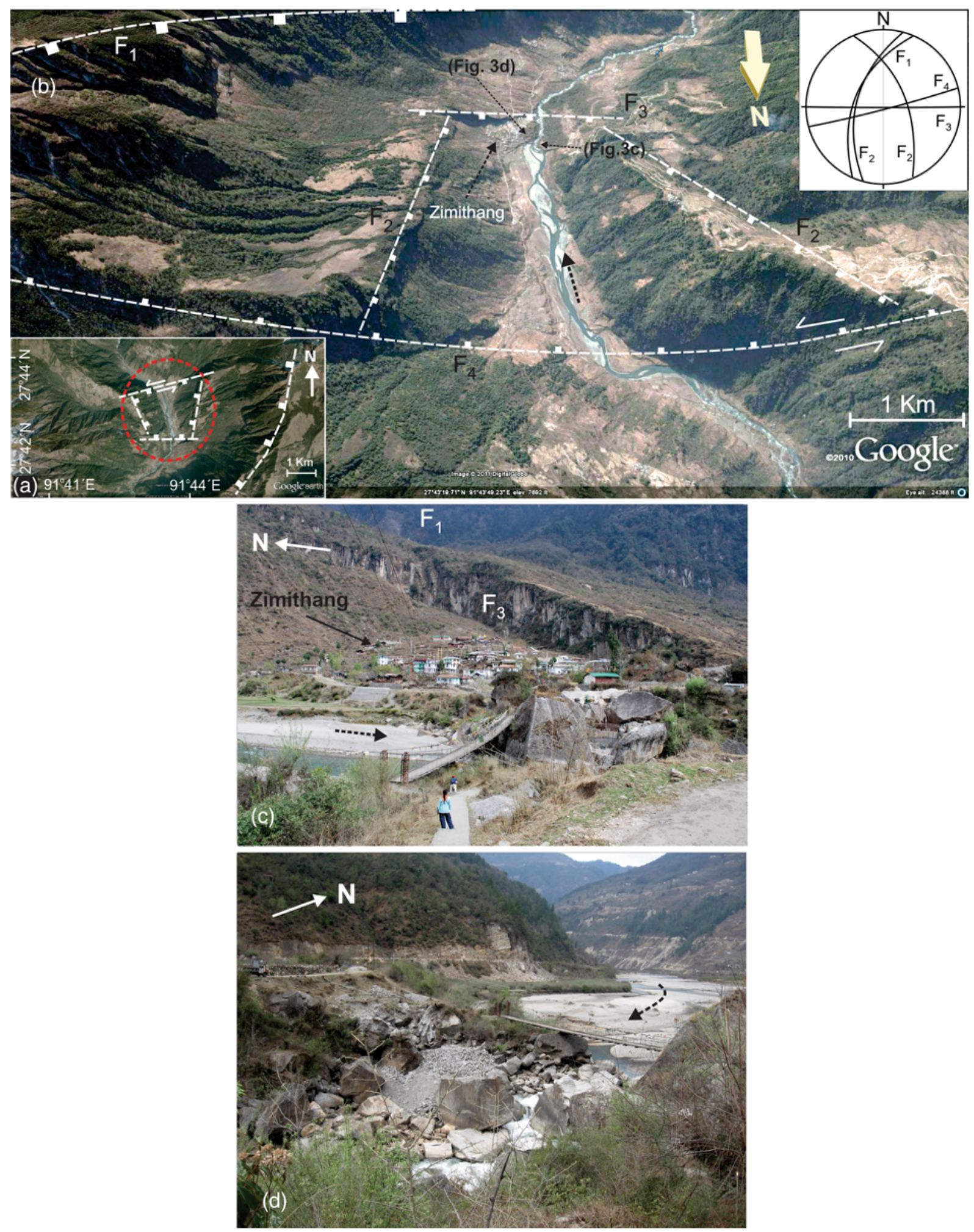

Figure 3. (a) Google-earth satellite image at Zimithang depicting the sudden change in the behaviour of the drainage pattern. Area within red ellipse is enlarged and demonstrated in (b). (b) Google-earth satellite image at Zimithang depicting arc-parallel extensional N-S trending half graben flanked by west dipping fault $\mathrm{F}_{1}$ (location shown in figure 1). The small graben is flanked by the $\mathrm{F}_{2}$ faults and bound at its southern end by north dipping normal fault $\left(\mathrm{F}_{3}\right)$, the northern end is flanked by normal cum sinistral fault $\left(\mathrm{F}_{4}\right),(\mathbf{c})$ vertical scarp face of the $\mathrm{F}_{3}$ fault in the eastern bank of the river, and (d) channel showing abrupt break in the river morphology from braided type drainage in the upstream to constricted bouldery channel in the downstream. Locations of (c) and (d) are shown in (b) with arrows indicating the photo direction. 
bounding $\mathrm{E}-\mathrm{W}$ faults $\left(\mathrm{F}_{3}\right.$ and $\left.\mathrm{F}_{4}\right)$ cut across the main fault $F_{1}$. A drastic change in river morphology is observed where the river crosses the fault $\mathrm{F}_{3}$. The narrow stretch of $\sim 2.5 \mathrm{~km}$ broad south flowing anastomosing river with several sand bars abruptly changes its morphology to a narrow river channel constricted by large boulders (figure $3 \mathrm{~b}-\mathrm{d}$ ) close to the fault $\mathrm{F}_{3}$. Similarly at the northern end close to fault $\mathrm{F}_{4}$, a constricted boulder laden channel in the north flows into a broad channel in the south. The stretch of anastomosing channel is observed only between fault $\mathrm{F}_{3}$ and $\mathrm{F}_{4}$ (figure $3 \mathrm{~b}$ ).

The Cona-Oiga rift cuts across STD and extends for only few kilometers towards south (Zhong-hai et al. 2008). However, the fault $\mathrm{F}_{1}$ in the western Arunachal cuts across the STD and extends further south close to MCT (figure 1). We interpret that the $\mathrm{E}-\mathrm{W}$ trending faults $\mathrm{F}_{3}$ and $\mathrm{F}_{4}$ have formed due to the collapse between the $\mathrm{N}-\mathrm{S}$ trending faults $\mathrm{F}_{2}$. The extensional faulting resulted in the formation of linear graben that is geomorphologically represented as broad anastomosing channel seen presently. The graben formation might have resulted in the formation of an elongated lake damming at its northern and southern ends by faults $\mathrm{F}_{3}$ and $\mathrm{F}_{4}$. However, the continued uplift of the Higher Himalaya provided greater slope towards south resulting in abandoning of lake and formation of anastomosing channel seen presently. The geomorphic evidences thus indicate periodic reactivation of E-W extension. Such reactivated extensional features were earlier documented by Armijo et al. (1986) in the southern Tibet. Low temperature thermochronological studies on migmatites from the $\mathrm{E}-\mathrm{W}$ river valley in Tawang revealed Apatite Fission Track (AFT) exhumation age of 1 Ma (De Sarkar et al. 2012). The Zimithang study area being only $30 \mathrm{~km}$ northwest of Tawang, we presume that the Zimithang zone might also have experienced similar exhumation history. This implies that the smaller graben formation at Zimithang might have occurred sometimes during Late Quaternary period post $\sim 1$ Ma. The formation of Zimithang graben in stages is represented schematically in figure 4 .

Yin et al. (2010) considered KakthangZimithang thrust as a regional out-of-sequence thrust in the hanging wall of MCT. The Kakthang thrust in Bhutan is considered out of sequence based on the youngest age of $12.5 \pm$ 0.4 Ma crystallization age from Khula Kangri granite (Edwards and Harrison 1997). According to Yin et al. (2010), the Kakthang thrust extends from Sikkim through Bhutan up to the central Arunachal Himalaya. Since the thrust passes through the Zimithang village, it was called as Khakthang-Zimithang thrust. The geomorphic

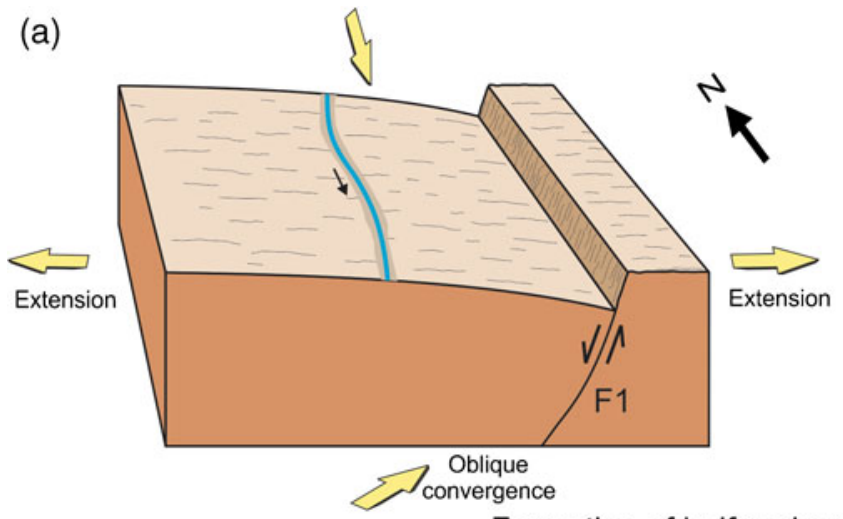

Formation of half graben
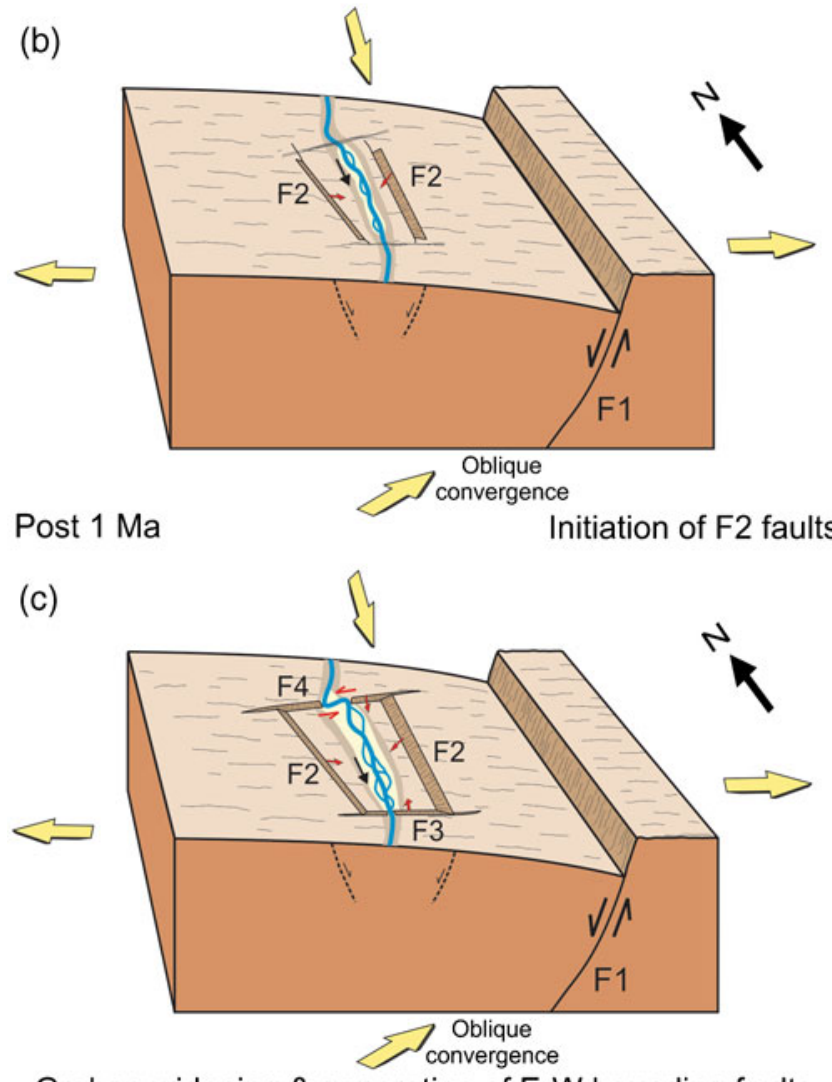

Graben widening \& generation of E-W bounding faults

Figure 4. Schematic model of Zimithang graben formation. (a) Formation of $\mathrm{F}_{1}$ half graben caused by arc-parallel extension, (b) initiation of $\mathrm{F}_{2}$ graben formation due to collapse of $\mathrm{F}_{1}$ half graben, post $1 \mathrm{Ma}$ and (c) widening of the graben and formation of $\sim \mathrm{E}-\mathrm{W}$ bounding faults $\left(\mathrm{F}_{3}\right.$ and $\left.\mathrm{F}_{4}\right)$ due to lake subsidence (see text for complete details). The broken lines along with the sense of movement on the front face of the block diagram (b and c) represent basin formation only within the small graben.

evidences discussed above on the drainage morphology change at Zimithang do not support the fault to be a thrust. The uplift of the hanging wall would have resulted in deep incision by the south flowing river. However, the field evidences indicate linear basin formation. In the DEM and geological map of Grujic et al. (2006) and 
Goswami et al. (2009), the Khakthang-Zimithang fault is shown passing south of Zimithang.

\subsection{Lesser Himalaya (Dirang valley)}

Most of the extensional structures shown in figure 1 are located around prominent morphological features such as the grabens. To document the pervasive distribution of these extensional structures in the Lesser Himalayas, we analysed incised fluvial terrace deposits. In the eastern Himalaya, the MCT can be traced almost continuously from Nepal, Sikkim and Bhutan to the eastern Himalayan syntaxis in Arunachal Pradesh (Gansser 1964, 1983; Mohan et al. 1989; Singh and Chowdhary 1990; Kumar 1997; Ding et al. 2001). In contrast to the broad shear zone in Bhutan, the MCT zone is exposed as contact between overlying sillimanite-kyanite migmatite, sillimanite-kyanite schist and underlying garnet-staurolite schist, phyllite, quartzite rocks in western Arunachal Pradesh (Singh and Chowdhary 1990; Goswami et al. 2009). During our investigation of fluvial terrace deposits south of MCT, a normal listric fault was observed at Dirang on a partially exposed face of a fluvial terrace deposit (figure 5a). To expose the fault trace, the face was scarped and cleaned. However, bottom part of the fault could not be exposed properly fearing collapse of the wall itself thereby affecting human settlement over the deposit. The incised terrace from the river valley is $\sim 45 \mathrm{~m}$ in height. The fault strikes $\sim 320^{\circ}$ and dips $20^{\circ}-25^{\circ}$

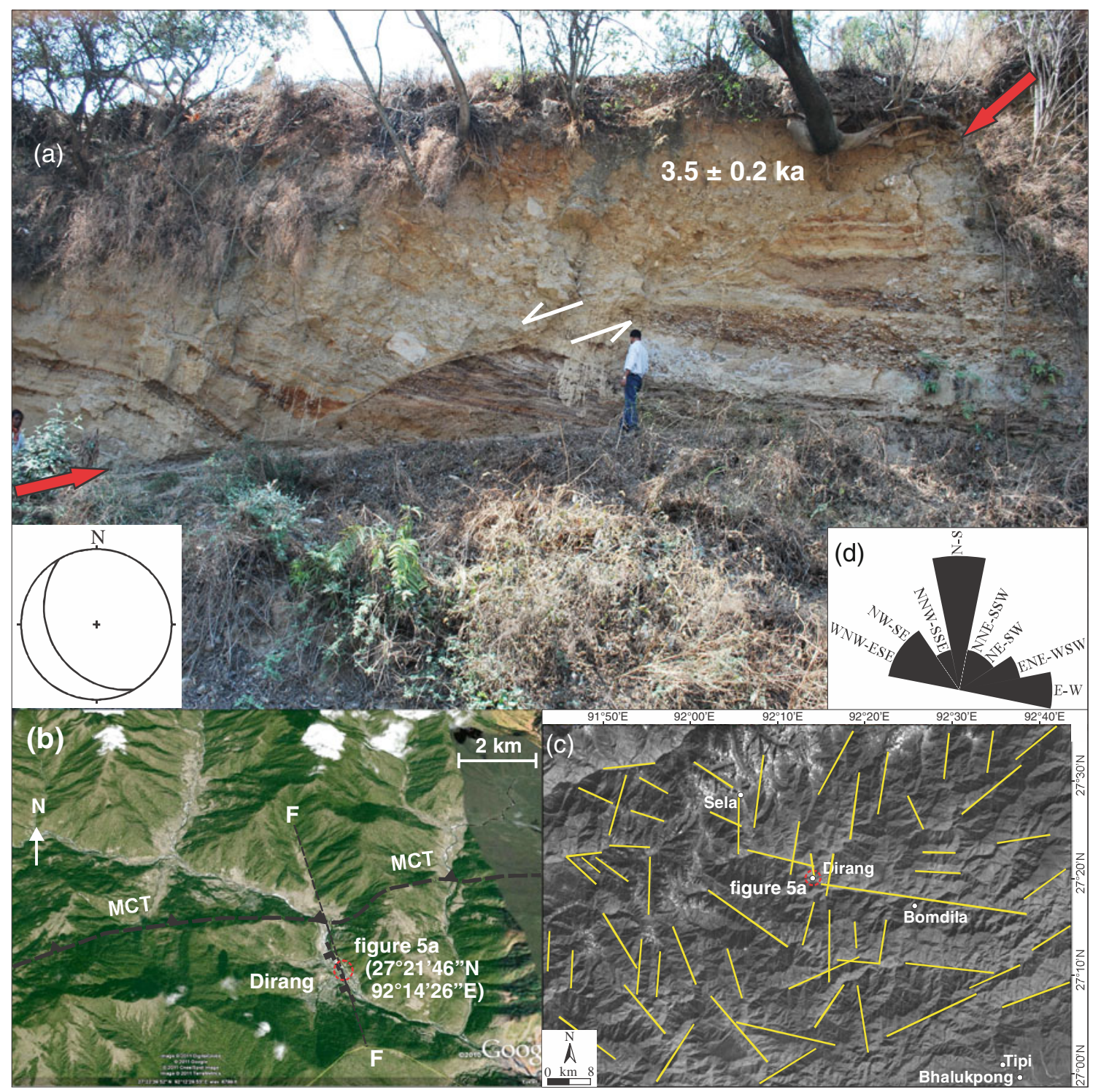

Figure 5. (a) Normal fault exposed within the Quaternary fluvial terrace at Dirang. Inset of stereogram shows the orientation of fault, (b) Google-earth satellite image of the area showing N-S gully erosional feature (F-F) along which the river makes a turn, (c) lineament map of the area. The location of normal fault is shown in (b) and (c), and (d) rose diagram of the lineament trends, showing majority of lineaments trending N-S attributed to the features related to E-W extension. 
due SW. The displacement, measured along the trace of the fault plane between the marker beds consisting of medium grained sand at the opposite sides of the fault, is $7.2 \mathrm{~m}$. The fault cuts through the upper exposed surface consisting of coarse debris flow deposit. The exposed scarp section shows cross stratified medium sand layer at the bottom, followed by a $1.2 \mathrm{~m}$ thick trough cross bedded medium grained sand layer with gravels, overlained by $0.8 \mathrm{~m}$ thick layer of fine sand and further by gravel bed of similar thickness as the fine sand layer (figure 5a). The upper thickest deposit is represented by a bouldary-gravel bed, consisting of large gneissic boulders. The largest boulder size is $\sim 0.4 \mathrm{~m}$. The lateral extension of this Quaternary fault into the Dirang quartzite was precluded due to thick vegetation in the entire area.

Optically Stimulated Luminescence (OSL) dating of upper coarse debris deposits was done to fix a lower time bound of the faulting event as OSL age of sediment gives the depositional age. Sediment sample was collected in a metal pipe from $\sim 1 \mathrm{~m}$ below the surface. Sample preparation was done under restricted light condition following the standard protocol. Equivalent dose (De) was estimated following SAR (single aliquote regenerative dose) protocol proposed by Murray and Wintle (2000, 2003). OSL signals were recorded at $125^{\circ} \mathrm{C}$ for $100 \mathrm{~s}$ through UV filter and a ${ }^{90} \mathrm{Sr} /{ }^{90} \mathrm{Y}$ beta source was used for irradiation. Equivalent dose (De) of the sample was $19 \pm 1.4$ Gy and uranium, thorium and potassium concentration of the sample gave annual dose rate of $5126 \pm 483 \mathrm{~Gy} / \mathrm{ka}$. The OSL age of the sample was estimated as $3.5 \pm 0.2 \mathrm{ka}$. The depositional age indicates the normal faulting event to be post $3.5 \mathrm{ka}$.

One of the characteristic geomorphologic features observed on extending Quaternary fault trace as shown in figure 5(b) is that the Bichom River is deflected close to the trend of the fault at Dirang from its original course. The river enters the fault zone and turns parallel to the normal fault trace and flows down and finally returns to its original flow direction. The trend of the Quaternary extensional fault and the trace of deflected stream also reveal extensive $\mathrm{N}-\mathrm{S}$ gully erosional features north and south of MCT (F-F in figure 5b). We interpret these features to have developed as a result of the E-W extension. Similar extensional features were also reported recently by Hintersberger et al. (2010) in the NW Himalaya based on satellite imagery.

While the N-S extensional features documented here are only two of the sporadic evidences in the western part of Arunachal Himalayas, the pervasive presence of similar features in the central and NW Himalaya (Hintersberger et al. 2010) indicate that such features may not be uncommon in $\mathrm{NE}$ Himalayas.

\section{Discussion}

\subsection{Cause for arc-parallel extension}

Normal faults at Zimithang indicate dominant E-W extension, while Dirang show ENE-WSW extension. Tectonic models explaining the formation mechanism of orogen-perpendicular graben in the Himalayan orogen includes:

- active east-west extension in Tibet to gravitational failure due to attainment of high elevation and spreading of its thick crust, called as the Lateral Extrusion model (Tapponnier and Molnar 1976; Molnar and Tapponnier 1978; Tapponnier et al. 1982; Valli et al. 2007, 2008),

- extension in response to conjugate strike slip fault and eastward extrusion of Tibet (Armijo et al. 1986),

- extension due to outward radial expansion of the Himalayan thrust front, called the radial expansion or spreading model (Seeber and Armbruster 1984; Molnar and Lyon-Caen 1988; Seeber and Pecher 1998; Murphy and Copeland 2005),

- extension related to arcuate geometry of the subduction zone, called the oroclinal bending model (Klootwijk et al. 1985; Ratschbacher et al. 1994), - extension attributed to rapid uplift of the Tibetan Plateau caused by convective removal of the lower mantle lithosphere (England and Houseman 1989; Royden et al. 1997),

- E-W extension in southern Tibet is argued as reflection of the local boundary conditions such as oblique convergence between India and Asia, called the oblique convergence model (McCaffrey and Nabelek 1998),

- extension due to Tertiary mantle upwelling in eastern Asia and thermal weakening of the lithosphere (Yin 2000),

- extension on account of mass accumulation and dissipation process (Hodges et al. 2001),

- extensional features attributed to local extension to metamorphic dome formation (Aoya et al. 2005), and

- extension in NW Himalaya driven by collapse of Tibetan Plateau (Hintersberger et al. 2010).

The various above models thus reveal that a concrete and viable explanation to the extensional features in both Tibet and Himalaya still remains enigmatic and subject of considerable debate. There are still large unexplored regions in NE Himalayas. A comprehensive database of extensional features along the entire NE Himalayas will be of great importance to test the viability of existing and new theories that might arise. However, evidences provided in the present study are discussed based on the oblique convergence and radial expansion models only, as most of the 
extensional features can best be explained by these models.

\subsection{Oblique convergence model}

Structural and morphological features both at Zimithang and at Dirang reveal absence of evidences suggesting local doming. Within the Himalayan arc, both active normal and strikeslip faults are reported. The slip directions in general show arc-parallel characteristics, resulting in both arc-parallel extension and translation (Ratschbacher et al. 1994; Murphy and Copeland 2005; Murphy and Burgess 2006; Thiede et al. 2006; Li and Yin 2008). The orientation of three independent grabens of the Cona-Oiga rift indicates a dextral en-echelon pattern (figure 1); however, there exists no report on the basins north and south bounding faults. At Zimithang, $\mathrm{F}_{4}$ fault associated with the north trending graben show left slip component along with dip slip (figure 3b). GPS vector data of Zhang et al. (2004) and Jade et al. (2007) with reference to Eurasia indicate that the geodetic vectors show normal orientation towards central and eastern parts of the Nepal Himalayan arc, while the convergence becomes progressively more oblique along the eastern Himalayan syntaxis (figure 1). Shen et al. (2005) and Allmendinger et al. (2007) have shown that the eastern Himalayan syntaxis show significant clockwise vertical axis rotation. The variation in convergence results in varying arc-parallel and arc-normal components relative to the Indian plate motion. The varying convergence would cause the total strain getting partitioned along the Himalayan arc into arc-normal shortening (thrusts), arc-parallel extension (rifts/normal faulting) and translation (strike-slip faults). The regional compressive stress direction turns from NE in the NW Himalaya, through north in the central Himalaya to NNW in NE Himalaya (figure 1). Extensional force acts perpendicular to the compressive force. Therefore, an arc-parallel extensional regime develops perpendicular to the direction of shortening.

We attribute the Zimithang graben, sinistral faulting and the evidence of normal faulting at Dirang as evidence of arc-parallel relieving of the strain in this region contemporaneous with the compressive phase. With regard to the earthquake focal mechanism, the seismic event B (figure 1) close to Bomdila in the year 1995 of $M_{w} \sim 5.4$ indicates dominant arc-parallel normal-slip component mechanism. The events $\mathrm{A}$ and $\mathrm{C}$ show strike slip components, while event $\mathrm{D}$ indicates dominant NW-SE contraction. The seismic events E and F reveal dip slip components close to STD, however, the event $G$ at the syntaxial zone show $\sim \mathrm{N}-\mathrm{S}$ normal faulting associated with translation movements. We presume that this is due to the sinistral movement at the eastern end of STD and dextral movement over the Jiali fault.

The Quaternary evidences at Zimithang and Dirang and the seismic events (B and $G$ ) reflects active arc-parallel extension mechanism along the strike of the eastern Himalayan arc, resulting in arc-perpendicular normal faulting and arcparallel sinistral faulting. The left-slip faulting at Zimithang if accounted along with the extent of other left-slip fault zone in the eastern Himalaya, such as the dominant left-slip fault in the eastern syntaxial area (figure 1) of Namche Barwa (Burg et al. 1998; Ding et al. 2001) indicates that the eastern Himalaya shows distinct contrast to the right-slip deformation dominant in the northwestern Himalaya (Karakoram fault in figure 1). The block model experiment of McCaffrey and Nabelek (1998) supports and demonstrates our interpretation of sinistral slip fault in the western Arunachal Himalaya. The block model experiment showed convincing evidences on the cause for radial slip vectors, arc-parallel translation and stretching occurring on account of oblique convergence. The oblique thrusting of India beneath the Himalayas and Tibet results in partitioning of the oblique convergence due to drag shear of the subducting plate. In the oblique convergence model, Indian plate motion, relative to Eurasian plate (red arrows), has an arc-normal component (blue arrows) and an arc-parallel component (white arrows) causing arc-parallel extension and along strike translations of the Himalaya (figure 1). These are manifested along the Himalayan arc as N-S extensional faulting and dextral slip faulting in NW Himalayas, absence of significant translational faults but presence of arc-perpendicular normal faults in central part of Nepal, sinistral slip faulting and normal faulting in the NE Himalayas (figure 1). The extension driven by the basal shear can affect the upper plate at any elevations (McCaffrey and Nabelek 1998).

\subsection{Radial expansion model}

The outward radial expansion or spreading model of the Himalayan arc (Murphy and Copeland 2005; Murphy et al. 2009) also provides satisfactory explanation towards the arc-parallel extension following arc-normal shortening. As thrust wedge propagates towards foreland developing new thrust at the front, contemporaneous arc-parallel extension occurs at the back. The vertical stress being minimum (thrust) in the foreland becomes maximum (normal fault) or intermediate (strike slip fault) in the hinterland part. The model states that the collisional arc expands radially outward along a single thrust without deforming the 
underthrusting lithospheric plate, while the thrust front suffers extensive extension. In a system of multiple thrusts like Himalaya, extension will be more active in the hinterland regions and decrease towards the foreland, as older thrust sheets in the hinterland gets greater radial push and therefore, gets translated to maximum distance than the younger thrust sheets in the foreland, where the convergence exceed expansion. Thus, the zone of crustal shortening propagates towards foreland creating space for zone of crustal expansion in the hinterland.

The amount of arc-parallel expansion is directly related to the amount of radial shortening. Murphy et al. (2009) proposed an equation to compute arc-parallel extension from the amount of arcnormal shortening. The magnitude of extension is expressed as:

$$
E=R \alpha \pi / 180
$$

where $E$ is the amount of arc-parallel extension, $R$ is the amount of arc-normal shortening and $\alpha$ is the angle of the arc segment taken into consideration.

Bendick and Bilham (2001) considered the shape of Himalayan arc as a small-circle centred at $92.1^{\circ} \pm$ $1.6^{\circ} \mathrm{E}$ longitude and $42.4^{\circ} \pm 2.1^{\circ} \mathrm{N}$ latitude with a radius of $1696 \pm 55 \mathrm{~km}$, which corresponds to an arc segment of $16.2^{\circ}$ or $1800 \mathrm{~km}$. However, this small-circle is applicable only for the arc segment between $77.2^{\circ}$ and $92.1^{\circ} \mathrm{E}$ latitudes (figure 1, broken yellow line). They considered four independent datasets to compute a single curve for the Tibet-Himalaya collision arc. Independent best fit curves were computed based on parameters, viz., maximum relief, seismicity, regional stress and fluvial knick points. Change in relief is the product of interaction between uplift rate and fluvial incision rate. If incision rate is assumed constant all along the arc-normal profile, high relief directly manifests high uplift rate. Quantitative measurement from leveling data indicates that the locations of maximum relief and maximum vertical velocity are coincident, through which one of the best fit curve has been drawn by Bendick and Bilham (2001). According to them the principal stress direction is dominantly arc-normal in the southern part of the collision zone, while it is vertical in the northern part. In the southern part, minimum stress direction is vertical. Therefore, arc-normal compression represents thrust related structures in Himalaya indicating maximum vertical velocity of deformed particles. A small-circle was therefore, fitted to the shallow earthquake events along the Himalayan arc which show arc-normal compression. Vertical compressive stress is minimum $\left(\sigma_{3}\right)$ in the south of Tibetan plateau while it is maximum $\left(\sigma_{1}\right)$ within the plateau (Molnar and Lyon-Caen 1989). They proposed from the earthquake focal mechanism data that the transition from minimum vertical stress $\left(\sigma_{3}\right)$ to maximum vertical stress $\left(\sigma_{1}\right)$ indicates the zone of continental collision which coincides to $4000 \mathrm{~m}$ contours. A small-circle was therefore, again drawn to fit the $4000 \mathrm{~m}$ contour in the Himalayan arc. River is considered as one of the best geomorphic indicator to tectonic activity. Fluvial knick points are the response of river related to active uplift in that area. Thus it also corresponds to the area of maximum vertical velocity. One independent small-circle was also drawn through the river knick points. Bendick and Bilham (2001) provided the final curve for the Himalayan arc after considering all the individual small-circles discussed above.

The NE Himalaya does not fall in the small-circle proposed by Bendick and Bilham (2001). Since the small-circle constructed based on topography show sudden divergence from the model arc due to Shillong Plateau, that accommodates large amounts of shortening, the small-circle proposed by Bendick and Bilham (2001) does not extend into the NE part of the Himalaya. Therefore, another small-circle is required to compute the NE Himalayan arc segment. We followed the criteria of state of stress suggested by Bendick and Bilham (2001) and fitted a small circle through $4000 \mathrm{~m}$ smoothed contour in the NE Himalayan region. The other data used by them were insufficient for the NE Himalaya to calculate an independent small circle; however, these meager data are qualitatively fitted well into the circle. We calculated circle equations through the contour points by keeping two end points of the contour fixed and varying the third in the middle and then took the mean of the centre and radius of those circles. The computed uncertainty is $1 \sigma$ standard deviation of the data. We propose a best fit small-circle for the NE Himalaya which is defined by the centre at $88^{\circ} 39^{\prime} \pm 0.7^{\prime} \mathrm{E}$ longitude and $33^{\circ} 40^{\prime} \pm 0.6^{\prime} \mathrm{N}$ latitude and radius of $770.7 \pm 15.1 \mathrm{~km}$ for the arc segment between $92^{\circ} 01^{\prime}$ and $95^{\circ} 16^{\prime} \mathrm{E}$ longitudes (figure 1, broken red line).

Yin et al. (2010) estimated the Cenozoic shortening of minimum $315 \mathrm{~km}$ from the map relationship in the northeastern Himalaya from the lateral stretch between $92.6^{\circ}$ and $94.7^{\circ} \mathrm{E}$ which falls within the $20^{\circ}$ arc segment of the proposed NE Himalayan small-circle in the present paper. Taking this shortening into account along the $20^{\circ}$ arc segment (figure 1), the amount of arc-parallel expansion computed based on equation (1) is $110 \mathrm{~km}$. The rate of $\mathrm{E}-\mathrm{W}$ extension in the southern Tibet is known from the geodetic study. Chen et al. (2004) illustrate that there is spatial non-uniformity in the extension pattern along the Himalayan arc and the rate of extension increases towards east. The extension rate computed between Lhasa and Gongbu 
(figure 1) is $\sim 13 \mathrm{~mm} / \mathrm{yr}$ (Chen et al. 2004). Timing of initiation of arc-parallel extension in the Himalaya and southern Tibet has been estimated by many authors. E-W extension in the south of Leo Pargil gneiss dome started at around $16 \mathrm{Ma}$ revealed by ${ }^{40} \mathrm{Ar} /{ }^{39} \mathrm{Ar}$ age of synkinematic micas on a fault plane (Hintersberger et al. 2010). Lee et al. (2011) reported that the age of initiation of the Kung Co rift extension is $\sim 12-13$ Ma based on zircon and apatite (U-Th)/He thermochronology. A range of 14-10 Ma has been suggested as the age of opening of the Thakkhola graben (Coleman and Hodges 1995; Garzione et al. 2000; Hurtado et al. 2001) in the western part of south Tibet. The onset of $\mathrm{E}-\mathrm{W}$ extension across the Yadong-Gulu rift was postulated from the stratigraphic relationship with South Tibetan Detachment fault. STD cuts the Khula Kangri granite (12.5 Ma) and was activated until $10 \mathrm{Ma}$, which imply that the E-W extension probably started after 10 Ma (Edwards and Harrison 1997). Harrison et al. (1995) reported $8 \mathrm{Ma}$ as the initiation age for Neogene extension of the plateau based on ${ }^{40} \mathrm{Ar} /{ }^{39} \mathrm{Ar}$ cooling age of Nyainqentanghla massif in the northwest of Yadong Gulu rift, while from the NE part of the Gulu rift, apatite (U-Th/He) thermochronology of the rocks from footwall suggest onset of extension around 7-5 Ma (Stockli et al. 2002). Due to the obliquity of India-Asia convergence, the arc-parallel extension in the southern Tibet and Himalaya initiated first in the western part and subsequently migrated towards east, as supported by the ages reported by various authors from different areas (figure 1). Thus, for the northeastern part of Himalaya, an age of $\sim 8 \mathrm{Ma}$ (Harrison et al. 1995) has been considered in the present study as the age of extension initiation. Based on the rate ( $\sim 13 \mathrm{~mm} / \mathrm{yr})$ of arc-parallel extension reported by Chen et al. (2004) and age of $8 \mathrm{Ma}$ as the initiation of extension (Harrison et al. 1995), imply a total extension of $\sim 104 \mathrm{~km}$. This corroborates closely with the amount $(110 \mathrm{~km})$ of extension calculated by the radial expansion model.

Analysis of the major lineaments in the study area (figure 5c) and its rose diagram (figure 5d) indicates that the first three higher frequencies fall in the trends of N-S, E-W and NW-SE respectively. The Himalayan range is mostly $\mathrm{E}-\mathrm{W}$ trending while in the northeastern segment it turns towards ENE-WSW. Major thrusts, which create the high relief, run parallel to the Himalayan arc. Thus the E-W lineaments follow arc-parallel compressive structures. The $\mathrm{N}-\mathrm{S}$ lineaments are evidences pointing towards the extensional features in the area.

The Quaternary arc-parallel extension evidences and mechanism suggested in the present paper indicate that there must be several pervasive extension related features along the NE Himalaya. Towards the syntaxial zone, translation related arc-parallel extension would dominate over the combination of north trending rift/normal fault and translation in the western and central parts of the Arunachal Himalaya. Further field studies, structural mapping and chronology would extend more conclusive evidences to understand the effective mechanism dominant in the NE Himalayas in particular and Indo-Tibetan collision dynamics in general.

\section{Conclusions}

The present study enables following inferences:

- There exist pervasive extensional related features in the NE Himalaya, extending from Tibet to the Lesser Himalaya. The Quaternary evidences of arc-parallel extension at Zimithang as graben, sinistral faulting and the evidence of normal faulting at Dirang suggest arc-parallel relieving of the strain in this region. The oblique thrusting of India beneath the Himalayas and Tibet resulted in partitioning of the oblique convergence due to drag shear of the subducting plate. The variation in oblique convergence along the Himalayan arc have resulted in the partitioning of strain along the Himalayan arc into arc-normal shortening (thrusts) and arc-parallel extension (rifts/normal faulting) and translation (strike-slip faults).

- Thrust wedge propagation towards foreland resulted in new frontal thrusts, while contemporaneous arc-parallel extension occurred in the hinterland regions. The amount of arc-parallel expansion is directly related to the amount of radial shortening. Analysis of the NE Himalayan arc segment based on considering a separate small-circle defined by the centre at $88^{\circ} 39^{\prime} \pm$ $0.7^{\prime} \mathrm{E}$ longitude and $33^{\circ} 40^{\prime} \pm 0.6^{\prime} \mathrm{N}$ latitude and radius of $770.7 \pm 15.1 \mathrm{~km}$ reveal that in the $20^{\circ}$ arc segment the amount of arc-parallel expansion is $\sim 110 \mathrm{~km}$. This corroborates closely with the amount of extension $\sim 104 \mathrm{~km}$ calculated based on the rate of $\mathrm{E}-\mathrm{W}$ extension and Neogene extension age estimate. The arc-parallel extensional features in the western Arunachal Himalaya can be explained satisfactorily by the oblique convergence and radial expansion models. However, this may not be entirely true for the Tibetan Plateau.

\section{Acknowledgements}

This work is a part of $\mathrm{PhD}$ dissertation of SDS with GM and KP. GM and KP acknowledge the funding provided by the Department of Science and 
Technology (DST) (IR/S4/ESF-04/2003) and Industrial Research and Consultancy Center (IRCC) (10IRCCBF002). SDS thanks CSIR, HRDG for the JRF fellowship. Authors thank Prof. A K Singhvi and Mr. P Chitrabhanu, GS-DN, Physical Research Laboratory, Ahmadabad for the OSL date. Authors also thank Mr. Kutubuddin Ansari for helping in calculation of the $\mathrm{NE}$ Himalayan small circle equation. They also thank the anonymous reviewers and Handling Editor, Prof. Somnath Dasgupta for their valuable comments and suggestions that helped to improve the paper.

\section{References}

Acharyya S K 1998 Thrust tectonics and evolution of domes and the syntaxis in Eastern Himalaya, India; J. Geol. Soc. Nepal 18 1-17.

Allmendinger R W, Reilinger R and Loveless J 2007 Strain and rotation rate from GPS in Tibet, Anatolia, and the Altiplano; Tectonics 26 TC3013 1-18.

Aoya M, Wallis S R, Terada K, Lee J, Kawakami T, Wang Y and Heizler M 2005 North-south extension in the Tibetan crust triggered by granite emplacement; Geology $\mathbf{3 3}$ 853-856.

Armijo R, Tapponnier P, Mercier J L and Han T L 1986 Quaternary extension in southern Tibet - Field observations and tectonic implications; J. Geophys. Res. 91(B14) 13,803-13,872.

Banerjee P and Bürgmann R 2002 Convergence across the northwest Himalaya from GPS measurements; Geophys. Res. Lett. 29(13) 1-4.

Bendick R and Bilham R 2001 How perfect is the Himalayan arc? Geology 29(9) 791-794.

Bhattacharjee S and Nandy S 2007 Geology of the western Arunachal Himalaya in parts of Tawang and West Kameng districts, Arunachal Pradesh; J. Geol. Soc. India 72 199-207.

Burchfiel B C and Royden L H 1985 North-south extension within the convergent Himalayan region; Geology 13(10) 679-682.

Burg J P, Nievergelt P, Oberli F, Seward D, Davy P, Maurin J C, Diao Z and Meier M 1998 The Namche-Barwa syntaxis: Evidence for exhumation related to compressional crustal folding; J. Asian Earth Sci. 16 239-252.

Chen Q, Freymueller J T, Yang Z, Xu C, Jiang W, Wang Q and Liu J 2004 Spatially variable extension in southern Tibet based on GPS measurements; J. Geophys. Res. 109 B09401 1-20.

Coleman M and Hodges K 1995 Evidence for Tibetan plateau uplift before 14 Myr ago from a new minimum age for east-west extension; Nature 374 49-52.

De Sarkar S, Mathew G, Pande K, Jonckheere R and Ratshbacher L 2012 Onset of denudation influenced rapid uplift around $1 \mathrm{Ma}$, Western Arunachal Himalaya, India; $34^{\text {th }}$ IGC Brisbane Australia, Session 19.3.

Ding L, Zhong D L, Yin A, Kapp P and Harrison T M 2001 Cenozoic structural and metamorphic evolution of the eastern Himalayan syntaxis (Namche Barwa); Earth Planet. Sci. Lett. 192 423-438.

Edwards M A and Harrison T M 1997 When did the roof collapse? Late Miocene N-S extension in the High Himalaya revealed by $\mathrm{Th}-\mathrm{Pb}$ dating of the Kula Kangri granite; Geology 25 543-546.
England P and Houseman G 1989 Extension during continental convergence with application to the Tibetan Plateau; J. Geophys. Res. 94(B12) 17,561-17,579.

Gansser A 1964 Geology of the Himalayas; Interscience Publishers, 465 289p.

Gansser A 1983 Geology of the Bhutan Himalaya; Birkhäuser Verlag, Basel, 181p.

Garzione C N, Dettman D L, Quade J, DeCelles P G and Butler R F 2000 High times on the Tibetan Plateau: Paleoelevation of the Thakkhola graben, Nepal; Geology 28(4) 339-342.

Goswami S, Bhowmik S K and Dasgupta S 2009 Petrology of a non-classical Barrovian inverted metamorphic sequence from the western Arunachal Himalaya, India; J. Asian Earth Sci. 36 390-406.

Grujic D, Coutand I, Bookhagen B, Bonnet S, Blythe A and Duncan C 2006 Climatic forcing of erosion, landscape, and tectonics in the Bhutan Himalayas; Geology 34 801-804.

Harrison T M, Copeland P, Kidd W S F and Lovera O M 1995 Activation of the Nyainqentanghla Shear Zone: Implications for uplift of the southern Tibetan plateau; Tectonics 14(3) 658-676.

Hintersberger E, Thiede R C, Strecker M R and Hacker B R 2010 East-west extension in the NW Indian Himalaya; Geol. Soc. Am. Bull. 122 1499-1515.

Hodges K V, Hurtado J M and Whipple K X 2001 Southward extrusion of Tibetan crust and its eject on Himalayan tectonics; Tectonics 20 799-809.

Hurtado J M, Hogdes K V and Whipple K X 2001 Neotectonics of the Thakkhola graben and implications for recent activity on the south Tibetan fault system in the central Nepal Himalaya; Geol. Soc. Am. Bull. 113(2) 222-240.

Jade S, Mukul M, Bhattacharyya A, Vijayan M, Jaganathan S, Kumar A, Tiwari R, Kalita S and Sahu S 2007 Estimates of interseismic deformation in northeast India from GPS measurements; Earth Planet. Sci. Lett. 263 $221-234$.

Jessup M J, Newell D L, Cottle J M, Berger A L and Spotila J A 2008 Orogen parallel extension and exhumation enhanced by denudation in the Trans-Himalayan Arun River gorge, Ama Drime Massif, Tibet-Nepal; Geology 36(7) 587-590.

Klootwijk C T, Conaghan P J and Powell C M 1985 The Himalayan arc - Large-scale continental subduction, oroclinal bending and back-arc spreading; Earth Planet. Sci. Lett. 75(2-3) 167-183.

Kumar G 1997 Geology of Arunachal Pradesh; Geol. Soc. India, Bangalore, 217p.

Lee J, Hager C, Wallis S R, Stockli D F, Whitehouse M J, Aoya M and Wang Y 2011 Middle to late Miocene extremely rapid exhumation and thermal reequilibriation in the Kung Co rift, southern Tibet; Tectonics $\mathbf{3 0}$ TC2007, doi: 10.1029/2010TC002745.

Leloup P H, Mahéo G, Arnaud N, Kali E, Boutonnet E, Liu D, Xiaohan L and Haibing L 2010 The South Tibetan Detachment shear zone in the Dinggye area: Time constraints on extrusion models of Himalayas; Earth Planet. Sci. Lett. 292 1-16.

Li D and Yin A 2008 Orogen-parallel, active left-slip faults in the Eastern Himalaya. Implications for the growth mechanism of the Himalayan Arc; Earth Planet. Sci. Lett. 274 258-267.

McCaffrey R and Nabelek J 1998 Role of oblique convergence in the active deformation of the Himalayas and southern Tibet Plateau; Geology 26 691-694.

Mohan A, Windley B F and Searle M P 1989 Geothermobarometry and development of inverted metamorphism 
in the Darjeeling-Sikkim region of the eastern Himalaya; J. Met. Geol. 7 95-110.

Molnar P and Chen W P 1983 Focal depths and fault plane solutions of earthquakes under the Tibetan Plateau; J. Geophys. Res. 88(B2) 1180-1196.

Molnar P and Lyon-Caen H 1988 Some simple physical aspects of the support, structure, and evolution of mountain belts; In: Processes in continental lithospheric deformation (eds) Clark S P, Clark B, Burchfiel B C and Suppe J; Geol. Soc. Amer. Special Paper 218 179-207.

Molnar P and Lyon-Caen H 1989 Fault plane solutions of earthquakes and active tectonics of the Tibetan plateau and its margins; Geophys. J. Int. 99 123-153.

Molnar P and Tapponnier P 1978 Active tectonics of Tibet; J. Geophys. Res. 83(B11) 5361-5375.

Murphy M A and Burgess W 2006 Geometry, kinematics, and landscape characteristics of an active transtension zone, Karakorum fault system, southwest Tibet; J. Struct. Geol. 28 268-283.

Murphy M A and Copeland P 2005 Transtensional deformation in the central Himalaya and its role in accommodating growth of the Himalayan orogen; Tectonics 24 TC4012 19p.

Murphy M A, Saylor J E and Ding L 2009 Late Miocene topographic inversion in southwest Tibet based on integrated paleoelevation reconstructions and structural history; Earth Planet. Sci. Lett. 282 1-9.

Murphy M A, Yin A, Kapp P, Harrison T M, Manning C E, Ryerson F J, Ding L and Guo J H 2002 Structural evolution of the Gurla Mandhata detachment system, southwest Tibet: Implications for the eastward extent of the Karakoram fault system; Geol. Soc. Am. Bull. 114 428-447.

Murray A S and Wintle A G 2000 Luminescence dating of quartz using an improved single aliquot regenerative-dose protocol; Radiation Measurements 32 57-73.

Murray A S and Wintle A G 2003 The single aliquot regenerative dose protocol: Potential for improvements in reliability; Radiation Measurements 37 377-381.

$\mathrm{Ni}$ J and Barazangi M 1984 Seismotectonics of the Himalayan collision zone - Geometry of the underthrusting Indian plate beneath the Himalaya; J. Geophys. Res. 89(B2) 1147-1163.

Ni J and York J 1978 Late Cenozoic tectonics of the Tibetan plateau; J. Geophys. Res. 83 5377-5384.

Ratschbacher L, Frisch W, Liu G H and Chen C S 1994 Distributed deformation in southern and western Tibet during and after the India-Asia collision; J. Geophys. Res. 99(B10) 19,917-19,945.

Royden L H, Burchfiel B C, King R W, Wang E, Chen Z L, Shen F and Liu Y P 1997 Surface deformation and lower crustal flow in eastern Tibet; Science 276 788-790.

Seeber L and Armbruster J 1984 Some elements of continental subduction along the Himalayan front; Tectonophys. 105 263-278.

Seeber L and Pecher A 1998 Strain partitioning along the Himalayan arc and the Nanga Parbat antiform; Geology 26 791-794.

Selverstone J 2005 Are the Alps collapsing? Ann. Rev. Earth. Planet. Sci. 33 113-132.
Shen Z, Lu J, Wang M and Bürgmann R 2005 Contemporary crustal deformation around the southeast borderland of the Tibetan plateau; J. Geophys. Res. 110 B11409 17p.

Singh S and Chowdhary P K 1990 An outline of the geological framework of the Arunachal Himalaya; J. Him. Geol. 1 189-197.

Stockli D F, Taylor M, Yin A, Harrison T M, D'Andrea J, Kapp P and Ding L 2002 Late Miocene-Pliocene inception of $\mathrm{E}-\mathrm{W}$ extension in Tibet as evidenced by apatite U-Th/He data; Geol. Soc. Amer. Abstr. Programs 34 411.

Styron R H, Taylor M H and Murphy M A 2011 Oblique convergence, arc-parallel extension, and the role of strikeslip faulting in the High Himalaya; Geoshpere $\mathbf{7 ( 2 )}$ 582-596.

Tapponnier P and Molnar P 1976 Slip-line field theory and large-scale continental tectonics; Nature 264 319-324.

Tapponier P, Peltzer G, Le Dain A Y, Armijo R and Cobbold P 1982 Propagating extrusion tectonics in Asia: New insights from simple experiments with plasticine; Geology 10 611-616.

Thiede R C, Arrowsmith J R, Bookhagen B, McWilliams M, Sobel E R and Strecker M R 2006 Dome formation and extension in the Tethyan Himalaya, Leo Pargil, northwest India; Geol. Soc. Am. Bull. 118 635-650.

Valdiya K S 1980 The two intracrustal boundary thrusts of the Himalaya; Tectonophys. 662 323-348.

Valli F, Arnaud N, Leloup P H, Sobel E R, Mahéo G, Lacassin R, Guillot S, Li H, Tapponnier P and $\mathrm{Xu} \mathrm{Z} 2007$ Twenty million years of continuous deformation along the Karakorum fault, western Tibet: A thermochronological analysis; Tectonics 26 TC4004, doi: 10.1029/2005TC001913.

Valli F, Leloup P, Paquette J, Arnaud N, Li H, Tapponnier P, Lacassin R, Guillot S, Liu D and Deloule E 2008 New $\mathrm{U}-\mathrm{Th} / \mathrm{Pb}$ constraints on timing of shearing and long term slip-rate on the Karakorum fault; Tectonics 27 TC5007, doi: 10.1029/2007TC002184.

Yin A 2000 Mode of Cenozoic east-west extension in Tibet suggesting a common origin of rifts in Asia during the Indo-Asian collision; J. Geophys. Res. 105(B9) $21,745-21,759$.

Yin A, Dubey C S, Kelty T K, Webb A A G, Harrison T M, Chou C Y and Célérier J 2010 Geologic correlation of the Himalayan orogen and Indian craton: Part 2. Structural geology, geochronology, and tectonic evolution of the Eastern Himalaya; Geol. Soc. Am. Bull. 122 360-395.

Zeitler P K, Meltzer A S, Koons P O, Craw D, Hallet B, Chamberlain C P, Kidd W S F, Park S K, Seeber L, Bishop M and Shroder J 2001 Erosion, Himalayan geodynamics, the geomorphology of metamorphism; GSA Today 11(1) 4-9.

Zhang P, Shen Z, Wang M, Gan W, Bürgmann R, Molnar P, Wang Q, Niu Z, Sun J, Wu J, Hanrong S and Xinzhao Y 2004 Continuous deformation of the Tibetan Plateau from Global Positioning System data; Geology 32(9) 809-812.

Zhong-hai W, Yong-shuang Z, Dao-gong Hu, Xi-tao Z and Pei-sheng Y 2008 The Quaternary normal faulting of the Cona-Oiga rift; Seismol. Geol. 30(1) 144-160. 